\title{
Isozyme variations in the genus thalamita of family portunidae from the Coastal Waters of Pakistan
}

\begin{abstract}
The genus Thalamita ofthe family Portunidae distributed in intertidal zone, especially in rocky shore. They are important to economically because fishermen can take their meat to sell at high price and also used as bait. Due to the privation scientific information and no work has been done on these species, especially from a biochemical and genetic perspective, consequently the present preliminary study attempted to evaluate the genetic variation in morphologically similar species of genus Thalamita by the use of electrophoresis. Isozyme variations were determined in four Thalamita spp, and seven enzyme system was selected, the study was revealed that the genetic diversity was highest in $T$. danae as compared to $T$. admete, and $T$. crenata and the lowest in T. savignyi. Genetic identity and genetic distance were also observed to evaluate the relationship between species. This selective information will be helpful to assess the status of the species and provides basic data for further studies.
\end{abstract}

Volume 6 Issue I - 2017

\author{
Noor Us Saher,' Farah Naz,' Mustafa \\ $\mathrm{Kamal}^{2}$ \\ 'Centre of Excellence in Marine Biology, University of Karachi, \\ Pakistan \\ ${ }^{2}$ Department of Biotechnology, University of Karachi, Pakistan
}

Correspondence: Noor Us Saher, Centre of Excellence in Marine Biology, University of Karachi, Karachi 75270, Pakistan, Email noorusaher@yahoo.com

Received: July 19, 2017 | Published: July 31, 2017

Keywords: Thalamita, Native PAGE, Electrophoresis, Pakistan

\section{Introduction}

In many studies enzyme polymorphisms can be used as molecular markers in the species identification, phylogenetic and population analysis and become a major tool for systematic and are also useful to fishery biologist to solve taxonomic problems ranging between species and populations Chow et al., 1993. The electrophoresis of enzymes on starch or polyacrylamide gels provides a powerful test of the validity of presumed species and is also considered as a simple and direct method, an efficient tool to determine the genetic variations among species and reveals the genetic changes as well as to determine the isozyme marker distinguishing two morphological similar species. ${ }^{1}$ Allozyme electrophoresis method is one of the most appropriate and often the method of choice for studies of population genetic structuring, species boundaries and hybridization. Because this technique allows the measurement of genetic distances between individuals, it can serve as a means for identifying similar species. ${ }^{2,3}$

The crabs of family Portunidae Rafinesque, 1815, are commonly known as swimming crabs, with high economic and commercial values throughout the world, besides the commercial value, they are one of the most biodiverse groups, occupied a variety of niches. The genus Thalamita of the family Portunidae distributed in the intertidal zone, especially in rocky shore and seagrass bed. They are important to economically because fishermen can take their meat to sell at high price and also used as bait. Preliminary observations revealed that these swimming crabs are carnivorous in nature and preys on fiddler crabs (genus Uca) as well as digs for bivalves. These crabs are not the only predator in mangrove swamps; also impact on the ecosystem is certainly very strong on account of its density in habitat. ${ }^{4}$ Due to the very little scientific information and no work has been done on these species, especially from a biochemical and genetic perspective. This study will be an initial step to a determination of existing species and evaluation of the genetic diversity. This information will also be helpful to assess the status of the species and provides basic data for further studies.

The main objective of this study, in order to reveal that either intraspecific genetic variation among the genus Thalamita can be identified using native PAGE polyacrylamide gel electrophoresis
(Native-PAGE) of various isozymes as well as the role and significance of these molecules as biomarkers for particular species.

\section{Materials and methods}

\section{Sample collection}

The representatives of genus Thalamitawere collected directly from the field by direct hand pick from the coast of Pakistan (Table 1). On capture or purchased live crabs immediately store in ice box, and transferred to the laboratory, killed by freezing and stored at $-20^{\circ} \mathrm{C}$ prior to tissue extraction.

Table I List of species studied, with collection locations and the number of individuals examined $(n)$

\begin{tabular}{lll}
\hline Species & Abbreviation & n \\
\hline Subfamily Thalamitinae & & \\
Genus Thalamita Litreille I892 & & \\
Thalamita crenata(Litreille I892) & TC & 20 \\
Thalmita danae(Stimpson I858) & TD & 20 \\
Thalamita admete(Herbst, I803) & TA & 16 \\
Thalamita savignyi(A. Milne Edwards, I86I) & TS & 14 \\
\hline
\end{tabular}

\section{Laboratory analysis}

\section{Native Polyacrylamide Gel Electrophoresis}

The entire process of Native Polyacrylamide gel electrophoresis for general protein and isozyme variation was performed by following steps: extraction, separation and staining as described by Shaw and Parasad ${ }^{5}$ and Hebert and Beaton, (1993). For electrophoresis seven enzyme system Carbonate Dehydratase (CD) EC 4.2.1.1, Peroxidase (PER) EC 1.11.1.7, Creatine Kinase (CK) EC 2-7.3.2, Amylase (AMY) EC 3.2.1.1, Catalase (CAT) EC 1.11.1.6, Octanol Dehydrogenase (ODH) EC 1.1.1.73, Glucose -6- Phosphate Dehydrogenase (G6PDH) EC 1.1.1.49 and General protein (GP) EC (numbern-specific) were selected. The representatives of four Thalamita species: T. crenata, T. danae, T. admete, T. savignyi, were selected for the study. Approximately 250-300 mg of muscle tissues was removed from each specimen and placed in hand homogenizer to regiment in extraction buffer Tris-Citrate. The homogenate was centrifuged at $13500 \mathrm{rpm}$ 
for $5 \mathrm{~min}$ to remove solid tissue debris. The supernatant (enzyme extract) was filtered. This extract was either immediately used for electrophoresis or stored at $-20^{\circ} \mathrm{C}$. Polyacrylamide gel electrophoresis (Native-PAGE) was performed as described by Laemmli, 1970 under reducing conditions in the discontinuous electrode buffer system for isozyme variation. Gels were stained for enzyme activity, according to Shaw \& Prashad. ${ }^{5}$

\section{Data analysis}

The Relative mobility (Rm) of Isozymes was estimated according to Petrokas \& Siddiqui et al. ${ }^{6,7}$ The nomenclature of loci and allele designation to the standardized genetic nomenclature. ${ }^{8}$ Alleles at each locus were designated by letters in alphabetical order, starting with the alleles encoding the most nodal migrating isozyme. Arabic numerals were given for enzymes coded by more than one locus in order of decreasing anodal mobility. Allele sizes are given in relation to their nodal mobility relative to the most common allele, the size of which was set to 0.99 . Alternate alleles were designed as per their mobility, relative to the most common allele. A locus was defined as polymorphic if the frequency of one of its alleles is less than or equal to 0.99 .

Quantification of genetic diversity was measured by intraspecies and based on genotypic and allele frequencies of variants; na = observed number of alleles; ne $=$ effective number of alleles ${ }^{9}$ and I $=$ Shanon's Information index ${ }^{10}$ were calculated. The mean observed and expected heterozygosity $\left(\mathrm{H}_{\mathrm{o}}\right)$ and $\left(\mathrm{H}_{\text {exp }}\right)$ per locus for each species were calculated using unbiased estimates. ${ }^{11}$ Observed and expected portions of heterozygous genotypes at each locus were averaged over loci to obtain means, ${ }^{12,13}$ the number of polymorphic loci and percentage of polymorphic loci were computed. The mean unbiased genetic distance (D) and genetic identity (I) among the species were calculated from the allelic frequencies according to Nei. ${ }^{13}$

\section{Results}

\section{Native-PAGE Electrophoresis}

Four species of genus Thalamita, T. crenata, T. danae, T. admete, T. savignyi were screened for isozyme variations using Native-PAGE polyacrylamide gel electrophoresis.

For electrophoresis seven enzyme systems Carbonate dehydratase
(CD) EC 4.2.1.1, Peroxidase (PER) EC 1.11.1.7, Creatine Kinase (CK) EC 2-7.3.2, Amylase (AMY) EC 3.2.1.1, Catalase (CAT) EC 1.11.1.6, Octanol Dehydrogenase (ODH) EC 1.1.1.73, Glucose -6Phosphate Dehydrogenase (G6PDH) EC 1.1.1.49 and General protein (GP) EC (non-specific) were selected. A total of 31 loci was resolved in seven enzyme systems. Genetic variations were estimated through the mean observed number of alleles $(\mathrm{Na})$, mean effected number of alleles $(\mathrm{Ne}),{ }^{9}$ Heterozygosity $(\mathrm{H})$, Shannon's information index $(\mathrm{I})^{10}$ and percentage of polymorphic loci (PPL).

\section{Genetic variation}

The allele frequency and loci distribution showed variability in between all the four species of genus Thalamita as are shown in (Table 2). A total of 31 loci was resolved during the electrophoretic study. The highest number $(\mathrm{N}=22)$ of polymorphic loci was observed in the $T$. danae whereas the lowest $(\mathrm{N}=5)$ was observed in $T$. savignyi.

In $T$. admete total thirteen numbers of loci were observed as polymorphic (CD-1*, CD-3*, GP-2*, GP-3*, GP-4*, GP-5*, CAT$2 *$ CAT $-4 *$, CK- $1 *$ - CK-3*, PER-2* OCT-1*, AMY-3*) with the percentage of $41.4 \%$ whereas in T. savignyi, five numbers of loci were observed as polymorphic (CD-1*, CD-2*, CK-1*- G6PDH-3* and $\left.\mathrm{AMY}-3^{*}\right)$ in T. savignyi whereas the percentage of polymorphic loci was $16.13 \%$. Only nine loci (CD-1*, GP-1*, CAT-1*, CAT-2*, CK-1*, PER-1*, G6PDH-1*, OCT-1*, AMY-3*) were appeared as polymorphic. In $T$. danae the highest number (22) of polymorphic loci (CD-1*, CD-2*, CD-3*, CD-4*, CD-5*, GP-1*, GP-3*, GP-4*, GP-5*, CAT- ${ }^{*}$, CAT-2*, CAT-3* ${ }^{*}$ CK- $1 *$ - CK-2*, CK-3*, CK-5*, G6PDH-1*, OCT-1*, OCT-2*, AMY-1*, AMY-2* and AMY-3*) and the percentage of polymorphic loci was $70.97 \%$. The expected heterozygosity $(0.148 \pm 0.208)$ was observed in $T$. admete whereas in $T$. savignyi the observed heterozygosity was $(0.078 \pm 0.229)$ and expected heterozygosity was $(0.657 \pm 0.149)$. The observed heterozygosity in $T$. crenata was $(0.139 \pm 0.276)$ and expected heterozygosity was $0.098 \pm 0.181$. The observed heterozygosity was highest $(0.1516 \pm 0.2931)$ in $T$. danae. The mean number of observed alleles was also observed and highest in $T$ danae $(0.1516 \pm 0.2931)$ and then $T$. admete $(1.419 \pm 0.502)$, T.savignyi $(1.193 \pm 0.477), T$. crenata $(1.093 \pm 0.267)$. The mean effective number of alleles was also calculated in T. admete (1.242 \pm 0.375$),$ T. savingyi ( $1.093 \pm 0.267), T$. crenata $(1.161 \pm 0.321)$ and in $T$. danae $(1.501 \pm 0.620)$.

Table 2 Allele frequency distribution for seven enzymes system estimated in four species of genus Thalamita

\begin{tabular}{|c|c|c|c|c|c|c|c|c|c|c|c|}
\hline Locus & Alleles & TA & TS & TC & TD & Locus & Alleles & TA & TS & TC & TD \\
\hline$C D-I^{*}$ & $\begin{array}{l}*_{a} \\
*_{b} \\
*_{c} \\
*_{d} \\
*_{e} \\
*_{f}\end{array}$ & $\begin{array}{l}0.875 \\
0.125\end{array}$ & $\begin{array}{l}0.9286 \\
0.0714\end{array}$ & $\begin{array}{l}0.7500 \\
0.2500\end{array}$ & $\begin{array}{l}0.800 \\
0.200\end{array}$ & CK-2* & $\begin{array}{l}*_{a} \\
*_{b} \\
*_{c}\end{array}$ & 1.000 & 1.000 & 1.000 & $\begin{array}{l}0.5000 \\
0.5000\end{array}$ \\
\hline$C D-2 *$ & $\begin{array}{l}*_{a} \\
*_{b} \\
*_{c}\end{array}$ & 1.000 & $\begin{array}{l}0.6429 \\
0.1429 \\
0.2143\end{array}$ & 1.000 & $\begin{array}{l}0.900 \\
0.100\end{array}$ & CK-3* & $\begin{array}{l}*_{a} \\
*_{b} \\
*_{c} \\
*_{d}\end{array}$ & 1.000 & 1.000 & 1.000 & $\begin{array}{l}0.900 \\
0.100\end{array}$ \\
\hline$C D-3 *$ & $\begin{array}{l}*_{a} \\
*_{b} \\
*_{c} \\
*_{d}\end{array}$ & $\begin{array}{l}0.500 \\
0.500\end{array}$ & 1.000 & 1.000 & $\begin{array}{l}0.200 \\
0.2000 \\
0.6000\end{array}$ & CK4* & $\begin{array}{l}*_{a} \\
*_{b} \\
*_{c} \\
*_{d}\end{array}$ & 1.000 & 1.000 & 1.000 & 1.000 \\
\hline CD-4* & $\begin{array}{l}*_{a} \\
*_{b} \\
*_{c} \\
*_{d} \\
*_{e}\end{array}$ & 1.000 & 1.000 & 1.000 & $\begin{array}{l}0.3500 \\
0.100 \\
0.4000 \\
0.1500\end{array}$ & CK-5* & $\begin{array}{l}*_{a} \\
*_{b} \\
*_{c}\end{array}$ & 1.000 & 1.000 & 1.000 & $\begin{array}{l}0.9500 \\
0.1000\end{array}$ \\
\hline
\end{tabular}


Table Continued...

\begin{tabular}{|c|c|c|c|c|c|c|c|c|c|c|c|}
\hline Locus & Alleles & TA & TS & TC & TD & Locus & Alleles & TA & TS & TC & TD \\
\hline$C D-5 *$ & $\begin{array}{l}*_{a} \\
*_{b} \\
*_{c} \\
d\end{array}$ & 1.000 & 1.000 & 1.000 & $\begin{array}{l}0.0500 \\
0.4500 \\
0.1000 \\
0.4000\end{array}$ & PER-I* & $\begin{array}{l}*_{a} \\
*_{b} \\
*_{c}\end{array}$ & 1.000 & 1.000 & $\begin{array}{l}0.5000 \\
0.5000\end{array}$ & 1.000 \\
\hline GP-I* & $\begin{array}{l}*_{a} \\
*_{b} \\
*_{c} \\
*_{d}\end{array}$ & 1.000 & 1.000 & $\begin{array}{l}0.9500 \\
0.5000\end{array}$ & $\begin{array}{l}0.700 \\
0.300\end{array}$ & PER-2* & $\begin{array}{l}*_{a} \\
*_{b} \\
*_{c} \\
*_{d}\end{array}$ & 1.000 & 1.000 & 1.000 & 1.000 \\
\hline GP-2* & $\begin{array}{l}*_{a} \\
*_{b} \\
*_{c} \\
*_{d}\end{array}$ & $\begin{array}{l}0.565 \\
0.4375\end{array}$ & 1.000 & 1.000 & 1.000 & PER-3* & $\begin{array}{l}*_{a} \\
*_{b} \\
*_{c} \\
*_{d}\end{array}$ & 1.000 & 1.000 & 1.000 & 1.000 \\
\hline GP-3* & $\begin{array}{l}*_{a} \\
*_{b} \\
*_{c}\end{array}$ & $\begin{array}{l}0.8750 \\
0.1250\end{array}$ & 1.000 & 1.000 & $\begin{array}{l}0.800 \\
0.200\end{array}$ & GP6PDH-I* & $\begin{array}{l}*_{a} \\
*_{b} \\
*_{c} \\
*_{d} \\
*_{e} \\
*_{f}\end{array}$ & 1.000 & 1.000 & $\begin{array}{l}0.9500 \\
0.0500\end{array}$ & $\begin{array}{l}0.7000 \\
0.3000\end{array}$ \\
\hline GP-4* & $\begin{array}{l}*_{a} \\
*_{b} \\
*_{c} \\
*_{d} \\
*_{e}\end{array}$ & $\begin{array}{l}0.9375 \\
0.0625\end{array}$ & 1.000 & 1.000 & $\begin{array}{l}0.500 \\
0.500\end{array}$ & G6PDH-2* & $\begin{array}{l}*_{a} \\
*_{b} \\
*_{c}\end{array}$ & 1.000 & 1.000 & 1.000 & 1.000 \\
\hline$G P-5 *$ & $\begin{array}{l}*_{a} \\
*_{b} \\
*_{c} \\
*_{d}\end{array}$ & $\begin{array}{l}0.9375 \\
0.0625\end{array}$ & 1.000 & 1.000 & $\begin{array}{l}0.9500 \\
0.0500\end{array}$ & G6PDH-3* & $\begin{array}{l}*_{a} \\
*_{b} \\
*_{c} \\
*_{d}\end{array}$ & 1.000 & $\begin{array}{l}0.8571 \\
0.1429\end{array}$ & 1.000 & 1.000 \\
\hline GP-6* & $\begin{array}{l}*_{a} \\
*_{b} \\
*_{c} \\
*_{d}\end{array}$ & 1.000 & 1.000 & 1.000 & 1.000 & OCT $-I^{*}$ & $\begin{array}{l}*_{a} \\
*_{b} \\
*_{c} \\
*_{d} \\
*_{e}\end{array}$ & 1.000 & 1.000 & $\begin{array}{l}0.700 \\
0.300\end{array}$ & $\begin{array}{l}0.800 \\
0.200\end{array}$ \\
\hline CAT-I* & $\begin{array}{l}*_{a} \\
*_{b} \\
*_{c} \\
*_{d}\end{array}$ & 1.000 & 1.000 & $\begin{array}{l}0.8500 \\
0.1500\end{array}$ & $\begin{array}{l}0.2000 \\
0.8000\end{array}$ & OCT-2* & $\begin{array}{l}*_{a} \\
*_{b} \\
*_{c} \\
*_{d}\end{array}$ & 1.000 & 1.000 & 1.0 & $\begin{array}{l}0.2000 \\
0.2500 \\
0.4500 \\
0.1000\end{array}$ \\
\hline CAT-2* & $\begin{array}{l}*_{a} \\
*_{b} \\
*_{c} \\
*_{d} \\
*_{e} \\
*_{a}\end{array}$ & $\begin{array}{l}0.5625 \\
0.4375\end{array}$ & 1.000 & $\begin{array}{l}0.6500 \\
0.3500\end{array}$ & $\begin{array}{l}0.900 \\
0.100\end{array}$ & OCT-3* & $\begin{array}{l}*_{a} \\
*_{b}\end{array}$ & 1.000 & & 1.0 & 1.000 \\
\hline CAT-3* & $\begin{array}{l}*_{b} \\
*_{c} \\
*_{d}\end{array}$ & 1.000 & 1.000 & 1.000 & $\begin{array}{l}0.9000 \\
0.1000\end{array}$ & AMY-I* & $\begin{array}{l}*_{a} \\
*_{b}\end{array}$ & 1.000 & 1.000 & 1.0 & $\begin{array}{l}0.9500 \\
0.0500\end{array}$ \\
\hline CAT-4* & $\begin{array}{l}*_{a} \\
*_{b}\end{array}$ & 1.000 & 1.000 & 1.000 & 1.000 & AMY-2* & $\begin{array}{l}*_{a} \\
*_{b}\end{array}$ & 1.000 & 1.000 & 1.0 & $\begin{array}{l}0.9500 \\
0.0500\end{array}$ \\
\hline$C K-I^{*}$ & $\begin{array}{l}*_{a} \\
*_{b} \\
*_{c} \\
*_{d}\end{array}$ & 1.000 & $\begin{array}{l}0.500 \\
0.500\end{array}$ & $\begin{array}{l}0.6000 \\
0.3500 \\
0.0500\end{array}$ & $\begin{array}{l}0.8000 \\
0.1000 \\
0.1000\end{array}$ & AMY-3* & $\begin{array}{l}*_{a} \\
*_{b}\end{array}$ & 1.000 & $\begin{array}{l}0.8571 \\
0.1429\end{array}$ & $\begin{array}{l}0.9000 \\
0.1000\end{array}$ & $\begin{array}{l}0.9500 \\
0.0500\end{array}$ \\
\hline
\end{tabular}

\section{Genetic variations in four species of genus Thalamita}

Nei's Heterozygosity

The overall average of allele variability was estimated through Nei's heterozygosity, and was observed different in four studied species. The Nei's heterozygosity was highest in $T$. danae $(0.248 \pm$ $0.227)$ as compared to $T$. admete $(0.138 \pm 0.195)$, and $T$. crenata $(0.093$ $\pm 0.172)$ and the lowest in $T$. savignyi $(0.053 \pm 0.138)$ accordingly (Table 3).

\section{Shanon's Information Index (I)}

Shanon's Information Index (I) was also estimated to observe the genetic variations based on distribution of different allelles. The diversity (I) was highest in $T$. danae $(0.410 \pm 0.378)$ as compared to $T$. admete, T.savignyi and T. crenata (Table 3 ).

\section{Genetic Diversity and Genetic Identity}

The genetic distance was calculated by using Nei's Unbiased Measures of Genetic Identity and Genetic distance. ${ }^{11}$ The genetic 
distance among other species of the Portunids crabs. The genetic distance between two species of $T$. crenata and T. danae was (0.1407). The distance between $T$. admete and T. savignyi (0.512), whereas distance between $T$. admete and $T$. danae $(0.1669)$. The Genetic Identity between two species $T$. crenata and $T$. danae was (0.8688) whereas between $T$. admete and T. savignyi (0.9510), between $T$. admete and $T$. danae (0.869). The genetic identity between $T$. crenata and T. admete $(0.9539)$ and in between $T$. crenata and $T$. savignyi (0.9796) (Table 4).

Table 3 Summary of heterozygosity and genetic variations Nei (1987) statistics for all loci in four species of genus Thalamita

\begin{tabular}{|c|c|c|c|c|}
\hline & T. admete & T. savingyi & T. crenata & T. danae \\
\hline Observes homozygosty & $0.782 \pm 0.349$ & $0.927 \pm 0.224$ & $0.86 I \pm 0.276$ & $0.848 \pm 0.293$ \\
\hline Observes heterozygosity & $0.222 \pm 0.349$ & $0.078 \pm 0.229$ & $0.139 \pm 0.276$ & $0.152 \pm 0.293$ \\
\hline Expected homozygosity & $0.852 \pm 0.208$ & $0.943 \pm 0.149$ & $0.902 \pm 0.181$ & $0.738 \pm 0.239$ \\
\hline Expected heterozygosity & $0.148 \pm 0.208$ & $0.657 \pm 0.149$ & $0.098 \pm 0.181$ & $0.026 \pm 0.239$ \\
\hline Nei & $0.138 \pm 0.195$ & $0.053 \pm 0.138$ & $0.093 \pm 0.172$ & $0.248 \pm 0.227$ \\
\hline The number of polymorphic & 13 & 5 & 9 & 22 \\
\hline The percentage of polymorphic loci & 41.4 & 16.13 & 29.09 & 70.9 \\
\hline Sample size & 16 & 14 & 20 & 20 \\
\hline na $=$ Observed number of alleles & $1.419 \pm 0.502$ & 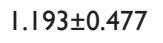 & $\mathrm{I} .323 \pm 0.54 \mathrm{I}$ & $1.968 \pm 0.875$ \\
\hline ne $=$ Effective number of alleles & $1.242 \pm 0.375$ & $\mathrm{I} .093 \pm 0.267$ & $1.161 \pm 0.321$ & $\mathrm{I} .50 \mathrm{I} \pm 0.620$ \\
\hline I = Shanon's Information index & $0.205 \pm 0.280$ & $0.086 \pm 0.220$ & $0.145 \pm 0.257$ & $0.410 \pm 0.378$ \\
\hline
\end{tabular}

Table 4 Estimates of Nei's ${ }^{\prime \prime}$ unbiased genetic distance $(D)$ (below diagonal) and genetic identity (I) (above diagonal) obtain in comparison among four species of genus Thalamita

\begin{tabular}{lllll}
\hline & T. admete & T. savingyi & T. crenata & T. danae \\
\hline T. admete & 0 & 0.9501 & 0.9539 & 0.8463 \\
T. savingyi & 0.0512 & 0 & 0.9796 & 0.869 \\
T. crenata & 0.0471 & 0.0206 & 0 & 0.8688 \\
T. danae & 0.1669 & 0.1404 & 0.1407 & 0 \\
\hline
\end{tabular}

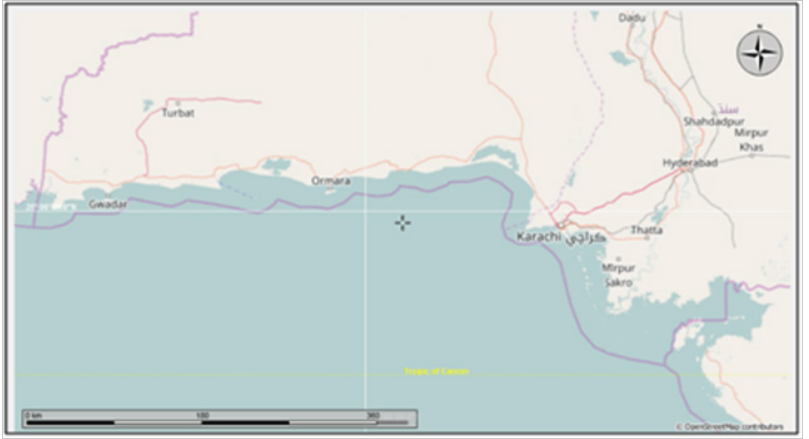

Figure I Map from the coastal waters of Pakistan.

\section{Discussion}

The isozyme patterns may provide additional information about the genetic structure of the species. The results presented here are based on electrophoresis pattern. Polyacrylamide gel electrophoresis was used to analyze muscle tissue of crabs for variations in seven enzymes system through native PAGE electrophoresis. A total of 31 allozymic loci was resolved in the four species of genus Thalamita. The polymorphic isozyme system has been used as an indicator to detect genetic variability in species. The intraspecific and interspecific variability was observed in the occurrence of polymorphic and monomorphic loci included the allele frequency distribution. A locus was considered as polymorphic if the most common allele was equal to or less than 0.99 . The highest number of polymorphic loci $(\mathrm{N}=22)$ were identified in T. danae.

The diversity and frequency of allele were also observed and calculated, varied among the studied species. The effective number of alleles varied in among the four species and was observed to be lowest in T. savignyi $(1.0931 \pm 0.2672)$. The Nei's heterozygosity was highest in T. danae compared to T. admete, T. savignyi and T. crenata. The genetic diversity (I) was highest in $T$. danae as compared to $T$. admete, T. savignyi and T. crenata. Xiang et al. ${ }^{14}$ observed the genetic diversity among the species of family Grapsidae in twelve enzyme loci and the average proportion of polymorphic loci was ranged between $0.167-0.083$ and heterozygosity was ranged in between (0.003-0.0020 respectively. The genetic variation is preliminary investigated within species and between different species in the present study and was found to be different in both. The expected and observed homozygosity and heterozygosity were also estimated through allele frequencies present on all loci. The lowest expected heterozygosity was estimated in $T$. danae $(0.02)$. Horii et al. ${ }^{15}$ was observed lowest average heterozygosity estimates in Decapoda: Ocypodidae: genus Macropthalamus spp ranged from (0.004-0.05); however, they were similar to those of other decapods' crustaceans. Powel1 $1{ }^{16}$ was also observed low heterozygosity $(0.15)$ in invertebrates, Sin and Jones ${ }^{17}$ was observed lowest heterozygosity $(0.038-0.045)$ in Ocypodid crabs: Macropthalamus hirtipes, (0-0.11) in Uca. Fushimi $\&$ Watanabe observed the highest mean heterozygosity (0.108) of the whole population of genus Scylla as compared to previously reported crustacean species; swimming crab Portunus trituberculatus (0.0070.014), snow crab Chinumberecetes opilio (0.0004-0.02), spider crab C. japonicus (0.072-0.077), and the hair crab Erimarcusisen beckii (0.023-0.032) mean heterozygosity. Fushimi \& Watanabe ${ }^{18}$ were also observed the mean heterozygosity in the Scylla species complex. Some studies suggested that low genetic variability in crustaceans provide insight towards the lowest rate of mutation ${ }^{19}$ or their mobility. ${ }^{20,15}$ The lowest values in heterzygosity provided the evidence or likely support to the low genetic variations is a phylogenetic character of decapods species (Gooch, 1977).

The genetic identity and genetic distance was also calculated for the estimation of genetic variability among different species and was found to be significantly different between the various Portunid 
species. The highest value of genetic identity ( $\mathrm{I}=0.9796)$ was estimated in between T. crenata and T. savignyi where as it was observed lowest $(0.5767)$ between $T$. admete and T. savignyi. Interspecific identityvalues obtained in this study, are comparable to interspecific values obtained in electrophoretic studies of a wide range of decapod Crustaceans and invertebrate taxa. ${ }^{20-22}$ This study helps us to assess the genetic diversity existing among species of genus Charybdis and also derive diagnostic loci and alleles that are useful for identification of closely related species. The lowest genetic identity among the different species of same family likely due to the environmental differences, habitat difference or reproductive isolation ${ }^{23}$ The Present study suggestd that these genetic variation can be considered as the preliminary investigate within species, between different species and for the baseline information for genotype studies through estimatation of intra and interspecies genetic distance. A present study helps us to assess the genetic diversity existing among four species of Thalamita crabs and can be used to evaluate levels of genetic diversity and phenotypic relationships within and between species. ${ }^{24-27}$

\section{Acknowledgements}

None.

\section{Conflicts of interest}

None.

\section{References}

1. Sujatha K, Deepti V, Shrikanya A, et al. Allozyme electrophoretic studies in four species of groupers (Pisces: Serranidae) represented in the commercial fishery of Visakhapatnam India. Indian Journal of GeoMarine Sciences. 2011;40(3):365-371.

2. Shaklee JB, Tamaru CS, Waples RS. Speciation and evolution of marine fishes studied by the electrophoretic analysis of proteins. Pac Sci. 1982;36(2):141-157.

3. Zhongbao L, Shaojing L, Guizhong W. Genetic diversity and differentiation of mud crab Scylla serrata population from southeastern China. 2004.

4. Cannicci S, Dahdouh-Guebas F, Anyona D, et al. Natural Diet And Feeding Habits Of Thalamita Crenata (Decapoda: Portunidae). J. Crustacean Biol. 1996;16(4):678-683.

5. Shaw CR, Prasad R. Starch gel electrophoresis of enzymes: a compilation of recipes. Biochemical Genetics. 1970;4(2):297-320.

6. Petrokas R, Stanys V. eaf peroxidase isozyme polymorphism of wild apple. Agron Rese. 2008;6(2):531-541.

7. Siddiquee S, Soon GT, Yus of UK. Isozyme Analysis and Relationships among Three Species in Malaysian Trichoderma Isolates. Microbiol Biote. 2010;20(9):1266-1275.

8. Shaklee JB, Allendorf FW, Morizot DC, et al. Gene nomenclature for protein-coding loci in fish. Trans Am Fish Soc. 1990;119:2-15.

9. Kimura M, Crow JF. The number of alleles that can be maintained in finite population. Genetics. 1964;49:725-738.
10. Lewontin RC. The apportionment of human diversity. Evol Biol. 1972;6:381-398.

11. Nei M. Estimation of average heterozygosity and genetic distance from a small number of individuals. Genetics. 1978;89(3):583-590.

12. Levene H. On a matching problem in genetics. Ann Math Stat. 1949;20(1):91-94.

13. Nei M. Analysis of gene diversity in subdivided populations. Proceedings of the National Academy of Sciences of USA. 1973;70(12):3321-3323.

14. Xiang GT, Mei XZ, Eiichi AB. Genetic relationship among seven Grapsidae species. Acta Hydrobiol Sin. 2000;24(6):622-629.

15. Horii T, Kitura J, Wada K, et al. Genetic relationship among Japanese sentinels crabs (Decpoda: Ocypodidae: genus Macrophthalamus). Comp Biochem Physiol Part B. 2001;130:75-82.

16. Powell JR. Protein variation in natural populations of animals. Evol Biol. 1975; 18:79-119.

17. Sin FYT, Jones MB. Enzyme variation in marine and estuarine populations of a mud crab, Macrophthalmus hirtipes (Ocypodidae). N. Z. J. Mar. Freshwater Res. 1983;17(4):367-372.

18. Fuseya R, Watanabe S. Genetic variability in the mud crab genus Scylla (Brachyura: Portunidae). Fisheries Science. 1996;62(5):705-709.

19. Nemeth ST, Tracey ML. Allozyme variability and relatedness in six crayfish species. J. Hered. 1979;70(1):37-43.

20. Hedgecock D, Tracey ML, Nelson K. Genetics. Abele LG (Ed), The Biology of Crustacea. Academic Press, New York, USA. 1982;pp.283403.

21. Thorpe JP. The molecular clock hypothesis: biochemical evaluation, genetic differentiation and systematics. Annu Rev Ecol Syst. 1982;13:139-168.

22. Thorpe JP, Solé-Cava AM. The use of allozyme electrophoresis in invertebrate systematics. Zool scripta. 1994;23(1):3-18.

23. Weber LI, Puchnick A, Lamego JP, et al. Genetic relationships among the most common swimming crabs Southern Brazil. J crust. Biol. 2003;23(1):201-211.

24. Herbst JFW. Versucheiner Naturgeschichte der Krabben und Krebsenebsteiner Systematischen Beschreibungihrer Verschiedenen Arten. Gottlieb August Lange, Berlin and Stralsund. 1782-1804;1$3,515,62$ pls.

25. Saher NU, Naz F, Siddiqa SM, et al. Study on isozyme electrophoretic patterns variability in the three species of super family Grapsoidea in Karachi mangrove forest. Int J boil Res. 2015;3(2):61-66.

26. Saher NU, Naz F, Siddiqa SM, et al. Variation of Carbonic Anhydrase (CA) isozyme in muscles of five species of Portunid crabs found in coastal waters of Pakistan. Int J Biol Biot. 2016;13(3):335-340.

27. Shaw CR, Prasad R. Starch gel electrophoresis of enzymes a compilation of recipes. Biochem Genet. 1970;4(2):297-320. 